\title{
KARAKTERISTIK PASANG SURUT DI TELUK JAKARTA BERDASARKAN DATA 253 BULAN
}

\author{
KARAKTERISTIK PASANG SURUT DI TELUK JAKARTA \\ BERDASARKAN DATA 253 BULAN
}

\author{
Aufi Dina 'Amalina1), Warsito Atmodjo'), Widodo Setiyo Pranowo' ${ }^{2) 3)}$ \\ ${ }^{1)}$ Departemen Oseanografi, Fakultas Perikanan dan Ilmu Kelautan, Universitas Diponegoro \\ ${ }^{2)}$ Laboratorium Data Laut dan Pesisir, Pusat Riset Kelautan, \\ Badan Riset dan Sumber Daya Manusia Kelautan dan Perikanan, Kementerian Kelautan dan Perikanan. \\ ${ }^{3)}$ Prodi Teknik Hidrografi, Sekolah Tinggi Teknologi Angkatan Laut. \\ e-mail : aufiamalina13@gmail.com
}

Diterima: 14 Juni 2019 ; Perbaikan: 02 Juli 2019 ; Disetujui: 15 Agustus 2019

\begin{abstract}
ABSTRAK
Pengetahuan mengenai kondisi pasang surut di Indonesia sangat penting sebagai pengukuran, analisis, dan pengkajia data muka air laut untuk berbagai kegiatan yang berhubungan dengan pantai maupun laut seperti pelayaran antar pulau, pencemaran laut, pengelolaan sumber daya hayati perairan atau pertahanan nasional, serta pembangunan konstruksi teknik sipil. Data yang digunakan adalah data pasang surut dan Peta Rupa Bumi Indonesia. Pengolahan data menggunakan perangkat lunak Microsoft Office Excel 2007 untuk pengolahan metode admiralty sedangkan Matlab R2014a pengolahan metode least square untuk menghasilkan komponen harmonik pasang surut. Hasil penelitian ini menunjukan bahwa tinggi muka pasang surut selama Maret 2018 mempunyai nilai elevasi MSL sebesar 1,91 meter ; elevasi MHWL sebesar 2,54 meter dan elevasi MLWL sebesar 1,27 meter. Sementara tinggi muka pasang surut selama Januari 1984 hingga Desember 2004 memiliki nilai tahunan berturut - turut sebagai berikut MSL sebesar 1,9482 meter; MHWL sebesar 2,8129 meter; dan nilai MLWL sebesar 1,0835 meter, sedangkan pada elevasi bulanan mempunyai elevasi MSL sebesar 1,9596 meter; MHWL sebesar 2,8057 meter; MLWL sebesar 1,1135 meter. Berdasarkan hasil analisis nilai formzahl dan tipe pasang surut dengan dua metode (Admiralty dan Least Square) pada Bulan Maret 2018 yaitu pada metode admiralty tipe campuran cenderung tunggal mempunyai nilai formzahl sebesar 2,6786, sedangkan untuk metode least square mempunyai nilai formzahl sebesar 3,7864 yang diklasifikasikan sebagai tipe pasang surut tunggal. Pada Januari 1984 hingga Desember 2004 metode admiralty mempunyai tipe pasang surut tunggal yang mempunyai bilangan formzahl sebesar 3,6924, sedangkan pada metode least square tipe pasang surut tunggal dengan nilai formzahl sebesar 4,6555 .
\end{abstract}

Kata kunci: Pasang Surut, Elevasi, Admiralty, Least Square, Teluk Jakarta.

\section{ABSTRACT}

The comprehension of tidal conditions in Indonesia is very important as measurement, analysis, and assessment of sea level data for various activities related to the coast and sea such as inter-island shipping, sea pollution, management of aquatic biological resources or national defense, as well as civil engineering construction. The data used are tidal data and Indonesia topographic Map. Data processing uses Microsoft Office Excel 2007 software for processing the admiralty method while Matlab R2014a of the least square method is used to produce tidal harmonic components. The results of this study indicate that it has different elevation values every year and month. Tidal levels during March 2018 had an MSL height of 1.91 meters; The MHWL elevation was 2.54 meters and the MLWL elevation was 1.27 meters. Whereas the high tidal level during January 1984 to December 2004 had the following annual values: MSL of 1.9482 meters; MHWL from 2.8129 meters; and the MLWL value was 1.0835 meters, while the monthly elevation had a height of MSL 1.9596 meters; MHWL 2,8057 meters; MLWL was 1.1135 meters. Based on the results of the formzahl value analysis and tidal type with two methods (Admiralty and Least Square) in March 2018 which is the mixed and single type tended admiralty method, had formzahl value of 2.6786, while the least square method had a formzahl value of 3.7864 which is classified as a single tidal type. From January 1984 to December 2004 the admiralty method had a 
single tidal type which had a formzahl number of 3.6924, whereas in the single square tidal type method had a formzahl value of 4.6555

Keywords: Tides, Elevation, Admiralty, Least Square, Jakarta Bay.

\section{PENDAHULUAN}

Indonesia merupakan negara kepulauan dengan sebagian besar wilayahnya merupakan perairan. Potensi perairan di Indonesia merupakan posisi strategis untuk pelayaran internasional maupun nasional, bahkan skala terkecil pelayaran antar pulau di Indonesia (Supriyono et al., 2015). Namun, pada potensi wilayah pesisir untuk perkembangan ekonomi sangat rentan terhadap kenaikan muka air laut. Banyak industri besar yang didirikan di wilayah pesisir karena kemudahan akses transportasi (Jamalludin et al., 2016). Untuk mendukung kegiatan pelayaran khususnya dan aktifitas yang dilakukan di perairan (transportasi air) pada umumnya, mutlak di ketahui gerakan naik dan turunnya permukaan air laut yang biasa disebut pasang surut (Supriyono et al., 2015).

Pasang surut laut merupakan gerakan naik turunnya permukaan laut yang disebabkan gaya tarik menarik antara bumi, bulan dan matahari. Selain gaya tarik menarik tersebut pengaruh meteorologis dan oseanografi juga ikut berperan dalam pembentukan karakteristik pasang surut, sehingga di setiap permukaan bumi memiliki kedudukan permukaan air laut yang bervariasi dari satu tempat ke tempat lain dan dari waktu ke waktu (Supriyono et al., 2015). Kedudukan permukaan air laut yang beraneka ragam meliputi Mean Sea Level (MSL), Highest High Water Level (HHWL), Lowest Water Level (LLWL) ini sangat sulit diprediksi dan perubahan sangat bergantung pada situasi dan lokasi (Muldiyatno et al., 2016). Kondisi amplitudo dan fase yang sangat bervariasi pada perairan Laut Jawa berkontribusi dalam tipe pasang surut yang dibentuk (Putra \& Pratomo, 2017). Untuk memahami sifat dan karakteristik pasang surut dibutuhkan data pasang surut yang lengkap, akurat dan bahkan diperlukan pengamatan yang cukup lama. Selain itu, sifat pasang surut yang periodik maka dapat diramalkan dengan mendapatkan nilai - nilai dari komponen - komponen pembentuknya (Supriyono et al., 2015). Sejauh ini, di wilayah perairan Indonesia mengalami keterbatasan data pasang surut yang disebabkan karena sulit dalam melakukan pengambilan data terutama di daerah lepas pantai (Gumelar et al., 2016)
Tujuan dari penelitian ini adalah untuk mengetahui nilai elevasi, komponen harmonik serta tipe pasang surut berdasarkan metode admiralty dan least square dengan data selama 253 bulan yang terhitung dari Januari 1984 hingga Desember 2004 serta Maret 2018 di Stasiun Pasang Surut Kolinlamil, Tanjung Priok, Jakarta.

\section{BAHAN DAN METODE}

\section{Materi Penelitian}

Materi yang digunakan pada penelitian ini meliputi data utama dan data penunjang. Data utama yaitu data pasang surut lapangan pada Stasiun Pasang Surut Kolinlamil yang diperoleh dari instansi Pusat Riset Kelautan, Badan Riset dan Sumber Daya Manusia Kelautan dan Perikanan, Kementerian Kelautan dan Perikanan - Republik Indonesia (BRSDM KP KKP). Stasiun Kolinlamil adalah stasiun pasang surut yang memiliki data pengamatan pasang surut dengan periode panjang yaitu 253 bulan yang terhitung dari Januari 1984 - Desember 2004, serta Maret 2018. Sedangkan, untuk data penunjang berfungsi sebagai pendukung data utama dalam pengolahan data agar data yang dihasilkan lebih akurat. Data penunjang yaitu peta Rupa Bumi Indonesia (RBI) Tahun 2016 dan data prediksi pasang surut di Teluk Jakarta. Pengolahan untuk memperoleh komponen harmonik menggunakan Toolbox T_Tide berbasiskan Matlab R2014a (Abida et al., 2015)

Metode yang digunakan adalah berupa metode eksperimen yang merupakan bagian dari metode kuantitatif karena pada metode ini dapat memberikan hasil yang bisa dilakukan ditempat lain (Nazir, 1988).

\section{Waktu dan Lokasi}

Penelitian dilaksanakan Maret - April 2018 di Teluk Jakarta, Jakarta Utara, DKI Jakarta. Teluk Jakarta terletak pada koordinat 6 4 '05" LS sampai 6 6 6 $55^{\prime \prime} \mathrm{LS}$ dan $106^{\circ} 52^{\prime} 45^{\prime \prime}$ sampai $106^{\circ} 54^{\prime} 15^{\prime \prime}$ BT. Penelitian ini terletak di Stasiun Kolinlamil, Tanjung Priok, Jakarta Utara, DKI Jakarta dengan koordinat $6^{\circ} 6^{\prime} 24.012$ " LS dan $106^{\circ} 53^{\prime} 24^{\prime \prime}$ BT 
Pasang Surut dengan Elevasi MSL, Komponen, Kedudukan Muka Air, dan Tipe Metode Admiralty

Menurut Ongkosongo \& Suyarso (1989), pengolahan metode admiralty ini berupa amplitudo (A) dan fase (g) dari tiap komponen pasang surut, bilangan formzahl (F) dan elevasi muka air. Tipe pasang surut dapat ditentukan dengan mengetahui nilai formzahl dengan rumus :

$$
\mathrm{F}=\frac{\mathrm{AK}_{1}+\mathrm{AO}_{1}}{\mathrm{AM}_{2}+\mathrm{AS}_{2}}
$$

Klasifikasi tipe pasang surut menurut Ongkosongo \& Suyarso (1989) sesuai dengan nilai formzahl tersebut yaitu:

Pasang surut harian ganda jika $\mathrm{F} \leq 0,25$;

Pasang surut campuran ganda jika $0,25<\mathrm{F} \leq 1,5$;

Pasang surut campuran tunggal jika $1,5<\mathrm{F} \leq 3$;

Pasang surut harian tunggal jika $F>3$

Hasil penentuan konstanta pasang surut yaitu amplitudo dan fase komponen pasang surut ini yang kemudian dapat menentukan prediksi elevasi pasang surut (Khatimah et al., 2016). Berdasarkan komponen pasang surut didapatkan nilai kedudukan muka air laut. Rumus yang digunakan menurut Pariwono dalam Ongkosongo \& Suyarso (1989) adalah sebagai berikut

Mean Sea Level $(\mathrm{MSL})=\mathrm{A}(\mathrm{So})$

Lowest Low Water Level $($ LLWL $)=\mathrm{A}(\mathrm{So})-[\mathrm{A}(\mathrm{M} 2)$

$+\mathrm{A}(\mathrm{S} 2)+\mathrm{A}(\mathrm{N} 2)+\mathrm{A}(\mathrm{K} 1)+\mathrm{A}(\mathrm{O} 1)+\mathrm{A}(\mathrm{P} 1)+\mathrm{A}(\mathrm{K} 2)$

$+\mathrm{A}(\mathrm{M} 4)+\mathrm{A}(\mathrm{MS} 4)]$

Highest High Water Level $(\mathrm{HHWL})=\mathrm{A}(\mathrm{So})+[\mathrm{A}(\mathrm{M} 2)$

$+\mathrm{A}(\mathrm{S} 2)+\mathrm{A}(\mathrm{N} 2)+\mathrm{A}(\mathrm{K} 1)+\mathrm{A}(\mathrm{O} 1)+\mathrm{A}(\mathrm{P} 1)+\mathrm{A}(\mathrm{K} 2)$

$+\mathrm{A}(\mathrm{M} 4)+\mathrm{A}(\mathrm{MS} 4)]$

Muka surutan $(\mathrm{Z} 0)=\mathrm{S} 0-1.2(\mathrm{M} 2+\mathrm{K} 2+\mathrm{S} 2)$

\section{Pasang Surut Metode Least Square}

Menurut Pawlowicz et al. (2002), pengolahan metode least square data pasang surut menggunakan software Matlab R2014a membuat script pasang surut dengan program $T_{-}$Tide. $T_{-}$Tide merupakan suatu alat bantu yang dapat digunakan untuk melakukan analisis harmonik dengan koreksi nodal. Persamaan pasang surut pada T_Tide dinyatakan dengan persamaan:

$$
v=\sum_{i^{\prime}=0}^{3}\left[\begin{array}{l}
G i^{(\theta) \sum_{j^{\prime} k^{\prime} l^{\prime} m^{\prime} n^{\prime}}} \\
+G i^{\prime}(\theta) \sum_{j k^{\prime} k^{\prime} l^{\prime} m^{\prime} n^{\prime}} B^{\prime}\left(j^{\prime} k^{\prime} l^{\prime} m^{\prime} k^{\prime} n^{\prime} m^{\prime} n^{\prime}\right) \cos (2 \pi V a) \\
\cos \left(2 \pi V_{a}\right)
\end{array}\right]
$$

Dengan $\mathrm{G}$ dan $\mathrm{G}$ ' adalah fungsi geodetic dengan tipe i' (tipe pelan, diurnal, dan semidiurnal adalah $0,1,2)$ dan lintang $\theta, A^{\prime}$, dan B' sebagai angka Doodson; Va sebagai argument astronomi, dan j'k'l'm'n' sebagai angka Doodson dengan konstanta tertentu (Pawlowicz et al., 2002).

Pengolahan data pasang surut dmenggunakan program Matlab T_Tide_v1.3Beta, daridatapasang surut diolah sehingga mendapatkan hasil berupa konstanta harmonik, kemudian disalin ke Microsoft Excel 2016 dan dipisahkan antara konstanta harmonik signifikan yang diambil Sembilan (9) konstanta harmonik yang umum digunakan sebagai perhitungan prediksi pasang surut dengan metode admiralty, selanjutnya rumus bilangan formzahl untuk menentukan jenis pasang surut. Data pasang surut dalam bentuk Microsoft Excel diubah kedalam bentuk notepad dan simpan data tersebut ke dalam folder T_Tide (Widisanto et al., 2016). Hasil analisis data pengamatan pasang surut yang adalah konstanta harmonik pasang surut dengan data frekuensi, amplitudo, kesalahan amplitude, fase, kesalahan fase, dan signal to noise ratio (SNR) sehingga dari nilai konstanta harmonik pasang surut dapat diperoleh nilai formzahl dan tipe pasang surut di daerah penelitian (Arifiyanto et al., 2016).

\section{Verifikasi Data}

Handoyo et al. (2015), verifikasi hasil dari perhitungan pasang surut yang dilakukan untuk membandingkan hasil pasang surut pengamatan di lapangan dengan prediksi pasang surut. Besar kesalahan yang terjadi dihitung dengan mencari nilai mean relative error (MRE). Perhitungan untuk mencari nilai tersebut dengan persamaan:

$\mathrm{MRE}=\left(\frac{\text { Pasang surut pengamatan } 1 \text { tahun }- \text { Pasang surut prediksi } 1 \text { tahun }}{\text { Pasang surut pengamatan }}\right) \times 100 \%$

\section{HASIL DAN PEMBAHASAN}

\section{Verifikasi Pasang Surut}

Berdasarkan data pengamatan lapangan dengan data peramalan pasang surut diperoleh nilai korelasi pada Januari 1984 hingga Desember 2004 diperoleh sebesar $82 \%$, sedangkan nilai RMSE diperoleh sebeesar $8 \%$. Hasil verifikasi pasang surut dapat ditunjukkan pada Gambar 1.

\section{Elevasi Muka Air}

Data dan informasi mengenai elevasi muka laut merupakan salah satu karakteristik perairan yang penting karena dengan mengetahui pola dinamika 


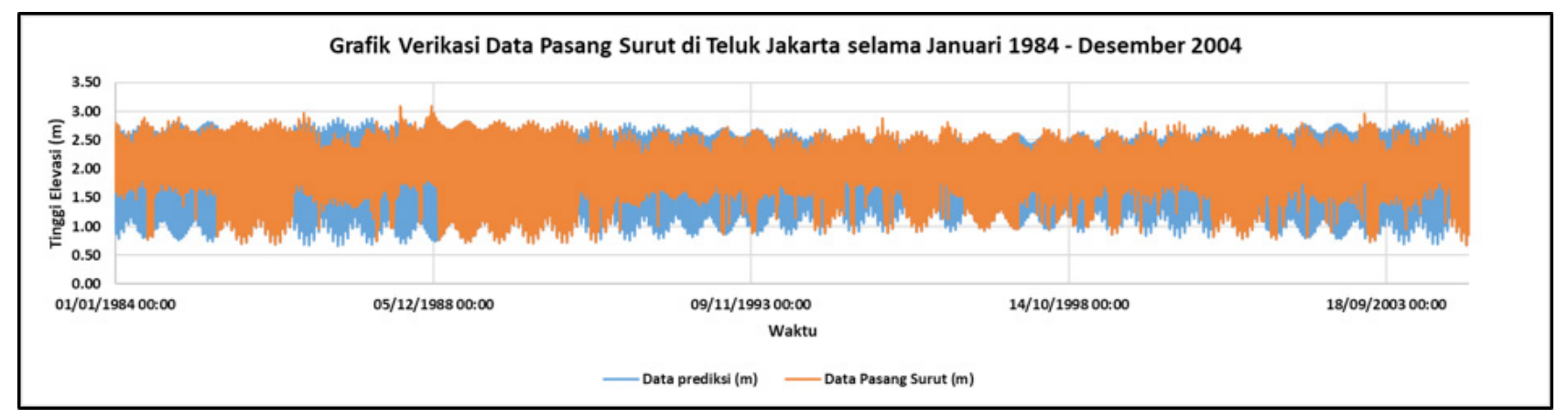

Gambar 1. Grafik Verifikasi Data Pasang Surut di Teluk Jakarta selama Januari 1984 - Desember 2004.

elevasi muka air dapat diketahui berbagai informasi kondisi fisis perairan, yaitu ketinggian muka air dan jangka waktu yang panjang (Trenggono et al., 2015). Poerbandono \& Djunarsjah (2005) bahwa elevasi muka air laut merupakan parameter yang sangat penting sebagai data acuan pengembangan wilayah pesisir dan bangunan pantai. Penentuan data ketinggian muka air pasang surut dilakukan dengan menggunakan metode admiralty untuk mencari nilai komponen komponen pasang surut hingga diketahui besarnya nilai MSL, HHWL, LLWL dan bilangan formzahl untuk menentukan jenis pasang surut dari perairan yang diteliti. Berdasarkan hasil perhitungan pasang surut dengan metode admiralty berupa nilai elevasi muka air. Elevasi muka air pasang surut di perairan Teluk Jakarta ini mempunyai nilai rerata elevasi yang berbeda pada elevasi tahunan dan elevasi Maret 2018. Adanya perbedaan di setiap perairan diduga dipengaruhi oleh posisi bulan terhadap bumi, faktor jarak antara bulan dengan bumi dan jarak antara bumi dan matahari dalam masing - masing lintasan orbit, faktor lokal yang tidak dapat diperhitungkan dalam metode admiralty meliputi tekanan atmosfir; densitas air laut; penguapan; arus laut; curah hujan; curah. Elevasi muka air pada bulanan ditentukan melalui nilai rerata muka air harian untuk waktu sebulan yang dipengaruhi oleh cuaca. Sedangkan pada elevasi muka air tahunan berubah dari tahun ke tahun walaupun perubahan tidak terlalu besar. Perubahan elevasi muka air ini disebabkan oleh kenaikan muka laut akibat pemanasan global atau akibat naik turunnya daratan akibat aktivitas seismik. Elevasi muka air pada metode least square tidak dapat dihitung karena pada $T_{-}$Tide bertujuan untuk menganalisa komponen harmonik pasang surut.

Hasil perhitungan analisa konstanta harmonik pasang surut pada Maret 2018 menunjukkan nilai Z0 sebesar 1,72 meter; MSL sebesar 1,91 meter; HHWL sebesar 2,54 meter; LLWL sebesar 1,27 meter; dan nilai Tunggang sebagai berikut 1,27 meter. Hasil pengukuran dapat dilihat pada Tabel 1 .

Berdasarkan nilai tahunan pada $Z_{0}$ nilai maksimum sebesar 1,92 meter; $Z_{0}$ nilai minimum sebesar 1,57 meter; dan $Z_{0}$ nilai rerata sebesar 1,75 meter. Untuk nilai pada MSL nilai maksimum sebesar 2,09 meter; nilai minimum sebesar 1,79 meter; nilai rerata sebesar 1,94 meter. Pada nilai MHWL dengan nilai maksimum sebesar 3,17 meter; nilai minimum sebesar 2,52 meter; dan nilai rerata sebesar 2,81 meter. Sedangkan nilai MLWL diperoleh nilai maksimum yaitu 1,36 meter; nilai minimum yaitu 0,63 meter; dan nilai rerata yaitu 1,08 meter. Sehingga diperoleh nilai tunggang nilai maksimum sebesar 2,53 meter; nilai minimum sebesar 1,17 meter; dan nilai rerata sebesar 1,72 meter. Hasil pengukuran dapat dilihat pada Tabel 2.

Teluk Jakarta dan Laut Jawa pada umumnya mempunyai tipe pasang surut tunggal dengan kisaran pasang surut (tidal range) yakni perbedaan tinggi muka air pada saat pasang maksimum dengan tinggi air pada saat surut minimum, rerata berkisar antara 1 hingga 3 meter. Perairan Laut Jawa pada umumnya mempunyai tunggang pasang surut sebesar 1 hingga 1,5 meter kecuali di Selat Madura, Tanjung Priok (Jakarta) hanya

Tabel 1. Hasil Perhitungan Elevasi (m) Metode Admiralty Bulan Maret 2018

\begin{tabular}{lccccc}
\hline \multirow{2}{*}{ Bulan } & \multicolumn{5}{c}{ Elevasi Bulan Maret 2018 (m) Rerata dengan Metode Admiralty } \\
\cline { 2 - 6 } & $\mathbf{Z}_{\mathbf{0}}$ & MSL & \multicolumn{2}{c}{ MHWL MLWL Tunggang } \\
\hline Maret 2018 & 1,720 & 1,909 & 2,544 & 1,274 & 1,270 \\
\hline
\end{tabular}


Tabel 2. Hasil Perhitungan Elevasi (m) Metode Admiralty Tahunan Rerata

\begin{tabular}{llllll}
\hline Tahun & \multicolumn{5}{c}{ Elevasi Tahunan (m) Rerata dengan Metode Admiralty } \\
\cline { 2 - 6 } & $\mathbf{Z}_{\mathbf{0}}$ & MSL & \multicolumn{3}{l}{ MHWL MLWL Tunggang } \\
\hline 1984 & 1,892 & 2,060 & 2,764 & 1,357 & 1,407 \\
1985 & 1,784 & 1,995 & 2,895 & 1,095 & 1,800 \\
1986 & 1,576 & 1,796 & 2,806 & 0,787 & 2,020 \\
1987 & 1,720 & 1,882 & 2,528 & 1,237 & 1,291 \\
1988 & 1,921 & 2,091 & 2,813 & 1,368 & 1,445 \\
1989 & 1,625 & 1,903 & 3,163 & 0,643 & 2,520 \\
1990 & 1,627 & 1,903 & 3,172 & 0,635 & 2,537 \\
1991 & 1,704 & 1,900 & 2,817 & 0,982 & 1,835 \\
1992 & 1,787 & 1,943 & 2,590 & 1,295 & 1,295 \\
1993 & 1,771 & 1,938 & 2,681 & 1,194 & 1,487 \\
1994 & 1,781 & 1,938 & 2,665 & 1,210 & 1,455 \\
1995 & 1,802 & 1,994 & 2,880 & 1,109 & 1,771 \\
1996 & 1,729 & 1,949 & 2,965 & 0,932 & 2,033 \\
1997 & 1,675 & 1,928 & 3,049 & 0,807 & 2,242 \\
1998 & 1,817 & 1,952 & 2,542 & 1,363 & 1,179 \\
1999 & 1,746 & 1,933 & 2,772 & 1,095 & 1,677 \\
2000 & 1,861 & 2,011 & 2,670 & 1,352 & 1,318 \\
2001 & 1,667 & 1,918 & 3,098 & 0,738 & 2,360 \\
2002 & 1,809 & 1,958 & 2,674 & 1,242 & 1,432 \\
2003 & 1,755 & 1,939 & 2,714 & 1,165 & 1,549 \\
2004 & 1,794 & 1,980 & 2,812 & 1,149 & 1,663 \\
& & & & &
\end{tabular}

berkisar 1 meter, Ambon berkisar 2 meter, Bagan Siapi - api berkisar 4 meter, sedangkan yang tertinggi di muara Sungai Digul dan selat Muli (Irian Jaya bagian selatan) mencapai sekitar 7 - 8 meter (Nontji, 1987). Menurut Haryono \& Narni (2004) bahwa karakteristik pasang surut di Laut Jawa sebagian merupakan pasang surut laut campuran condong ke harian ganda (Prigi, Cilacap, Jakarta, Surabaya) dan sebagian berupa pasang surut campuran condong ke harian tunggal (Jepara). Hal inilah tidak jauh dengan pendapat yang dikemukakan oleh Wyrtki (1961).

\section{Komponen Harmonik Amplitudo}

Pengetahuan tentang pasang laut sangat diperlukan dalam transportasi perairan, kegiatan di pelabuhan, pembangunan di daerah pesisir pantai, dan lain - lain. Sifat pasang laut yang periodik, sehingga dapat diramalkan. Untuk dapat meramalkan pasang laut, diperlukan data amplitudo dari masing - masing komponen pembangkit pasang laut. Komponen utama pasang surut terdiri dari komponen tengah harian, dan harian. Namun demikian, karena interaksi dengan bentuk morfologi pantai, superposisi antar komponen pasang laut utama, dan faktor yang lain akan mengakibatkan terbentuknya komponen - komponen pasang laut yang baru.

Hasil perhitungan komponen amplitudo (m) dengan metode admiralty yang diperoleh dari skema data pasang surut dengan menggunakan metode admiralty dengan konstanta harmonik pasang surut amplitudo yaitu M2, S2, N2, K1, O1, M4, MS4 , K2 dan P1 pada Maret 2018. Hasil pengukuran dapat dilihat pada Tabel 3 .

Berdasarkan data Januari 1984 hingga Desember 2004 pada perairan Teluk Jakarta diperoleh nilai maksimum pada masing - masing komponen S0, M2, S2, N2, K1, O1, M4, MS4, K2 dan P1. Hasil perhitungan komponen amplitudo (m) Tahunan Rerata dapat dilihat pada Tabel 4.

Tabel 3. Hasil Perhitungan Komponen Amplitudo (m) Metode Admiralty Bulan Maret 2018

\begin{tabular}{|c|c|c|c|c|c|c|c|c|c|c|}
\hline & S0 & M2 & S2 & N2 & K1 & 01 & M4 & MS4 & K2 & P1 \\
\hline $\mathrm{A}(\mathrm{m})$ & 1,91 & 0,07 & 0,07 & 0,02 & 0,26 & 0,11 & 3,75 & 0,24 & 0,2 & 0,09 \\
\hline
\end{tabular}


Hasil perhitungan komponen amplitudo (m) dengan metode least square yang diperoleh dari skema data pasang surut dengan menggunakan metode least square dengan konstanta harmonik pasang surut amplitudo yaitu M2, S2, N2, K1, O1, M4, MS4, K2 dan P1 pada Maret 2018. Hasil pengukuran dapat dilihat pada Tabel 5.

Hasil perhitungan komponen amplitudo (m) metode least square yang diperoleh dari skema data pasang surut dengan menggunakan metode least square dengan konstanta harmonik pasang surut amplitudo yaitu M2, S2, N2, K1, O1, M4, MS4, K2 dan P1 yang mempunyai nilai maksimum, nilai minimum, dan nilai rerata selama 252 bulan. Hasil perhitungan komponen amplitudo (m) Tahunan Rerata dapat dilihat pada Tabel 6.
Berdasarkan hasil komponen amplitudo metode admiralty yang menghasilkan nilai masing - masing komponen S0, M2, S2, N2, K1, O1, M4, MS4, K2 dan P1. Variasi amplitudo pasang surut di perairan teluk berasal dari empat proses fisik, yaitu resonansi gelombang berdiri dari refleksi gelombang datang saat pasang, efek gesekan, konvergensi geometri (pengurangan luas penampang ke arah pesisir), dan efek inersia. Resonansi dan konvergensi geometri pantai menyebabkan peningkatan amplitudo pasang surut jauh lebih besar dibandingan dengan pasang surut di laut terbuka. Resonansi gelombang berdiri mudah dipahami dalam hal saluran prismatik sederhana, yaitu gelombang dapat digambarkan sebagai hasil dari superposisi antara gelombang datang dan gelombang yang dipantulkan (Kusmanto et al., 2016). Sedangkan hasil komponen dengan menggunakan metode least square dengan data pada Maret 2018 dan Januari 1984

Tabel 4. Hasil Perhitungan Komponen Amplitudo (m) Metode Admiralty Tahunan Rerata

\begin{tabular}{llllllllllll}
\hline \multirow{2}{*}{ Tahun } & \multicolumn{8}{c}{ Komponen Amplitudo (m) Rerata dengan Metode Admiralty } \\
\cline { 2 - 10 } & S0 & M2 & S2 & N2 & K1 & O1 & M4 & MS4 & K2 & P1 \\
\hline 1984 & 2,06 & 0,07 & 0,05 & 0,02 & 0,29 & 0,16 & 4,07 & 0,31 & 0,01 & 0,09 \\
1985 & 1,99 & 0,10 & 0,06 & 0,03 & 0,35 & 0,22 & 4,15 & 0,32 & 0,02 & 0,11 \\
1986 & 1,95 & 0,14 & 0,05 & 0,03 & 0,43 & 0,28 & 4,22 & 0,32 & 0,01 & 0,14 \\
1987 & 1,88 & 0,06 & 0,06 & 0,02 & 0,26 & 0,14 & 4,25 & 0,32 & 0,02 & 0,09 \\
1988 & 2,09 & 0,08 & 0,05 & 0,02 & 0,29 & 0,16 & 4,24 & 0,33 & 0,01 & 0,10 \\
1989 & 1,90 & 0,16 & 0,05 & 0,02 & 0,48 & 0,33 & 4,20 & 0,32 & 0,01 & 0,16 \\
1990 & 1,90 & 0,16 & 0,05 & 0,03 & 0,48 & 0,33 & 4,13 & 0,32 & 0,01 & 0,16 \\
1991 & 1,90 & 0,11 & 0,04 & 0,03 & 0,36 & 0,22 & 4,04 & 0,31 & 0,01 & 0,12 \\
1992 & 1,94 & 0,06 & 0,05 & 0,02 & 0,27 & 0,14 & 3,94 & 0,31 & 0,01 & 0,09 \\
1993 & 1,94 & 0,07 & 0,05 & 0,02 & 0,31 & 0,16 & 3,85 & 0,30 & 0,01 & 0,10 \\
1994 & 1,94 & 0,07 & 0,05 & 0,02 & 0,29 & 0,17 & 3,77 & 0,29 & 0,01 & 0,10 \\
1995 & 1,99 & 0,10 & 0,05 & 0,03 & 0,35 & 0,21 & 3,70 & 0,29 & 0,01 & 0,11 \\
1996 & 1,95 & 0,12 & 0,05 & 0,03 & 0,40 & 0,25 & 3,67 & 0,29 & 0,01 & 0,13 \\
1997 & 1,93 & 0,14 & 0,06 & 0,03 & 0,43 & 0,28 & 3,67 & 0,29 & 0,01 & 0,14 \\
1998 & 1,95 & 0,05 & 0,05 & 0,03 & 0,25 & 0,12 & 3,69 & 0,29 & 0,01 & 0,08 \\
1999 & 1,93 & 0,09 & 0,05 & 0,03 & 0,34 & 0,19 & 3,74 & 0,30 & 0,01 & 0,11 \\
2000 & 2,01 & 0,07 & 0,05 & 0,03 & 0,27 & 0,14 & 3,82 & 0,30 & 0,01 & 0,09 \\
2001 & 1,92 & 0,15 & 0,05 & 0,03 & 0,46 & 0,30 & 3,91 & 0,30 & 0,01 & 0,15 \\
2002 & 1,96 & 0,07 & 0,04 & 0,04 & 0,29 & 0,16 & 4,01 & 0,31 & 0,01 & 0,10 \\
2003 & 1,94 & 0,09 & 0,05 & 0,02 & 0,32 & 0,17 & 4,10 & 0,32 & 0,01 & 0,10 \\
2004 & 1,98 & 0,09 & 0,05 & 0,03 & 0,33 & 0,20 & 4,18 & 0,32 & 0,01 & 0,11 \\
max & 2,09 & 0,16 & 0,06 & 0,04 & 0,48 & 0,33 & 4,25 & 0,33 & 0,02 & 0,16 \\
min & 1,88 & 0,05 & 0,04 & 0,02 & 0,25 & 0,12 & 3,67 & 0,29 & 0,01 & 0,08 \\
average & 1,96 & 0,10 & 0,05 & 0,03 & 0,34 & 0,21 & 3,97 & 0,31 & 0,01 & 0,11 \\
\hline & & & & & & & & & &
\end{tabular}

Tabel 5. Hasil Perhitungan Komponen Amplitudo (m) Metode Least Square Bulan Maret 2018

\begin{tabular}{lllllllllll}
\hline & & \multicolumn{8}{c}{ Komponen Amplitudo Tahunan (m) Rerata } \\
A(m) & M2 & S2 & N2 & K1 & O1 & M4 & MS4 & K2 & \multirow{2}{*}{ P1 } \\
\hline & \multirow{2}{*}{0,07} & 0,07 & 0,01 & 0,42 & 0,12 & 0,00 & 0,00 & 0,02 & 0,14 \\
\hline
\end{tabular}


Tabel 6. Hasil Perhitungan Komponen Amplitudo (m) Metode Least Square Tahunan Rerata

\begin{tabular}{lllllllllll}
\hline & \multicolumn{7}{c}{ Komponen Amplitudo (m) Rerata dengan Metode Least Square } \\
\cline { 2 - 9 } Tahun & M2 & S2 & N2 & K1 & O1 & M4 & MS4 & K2 & P1 \\
\hline 1984 & 0,06 & 0,05 & 0,02 & 0,29 & 0,16 & 0,01 & 0,00 & 0,01 & 0,10 \\
1985 & 0,09 & 0,01 & 0,02 & 0,36 & 0,22 & 0,00 & 0,00 & 0,00 & 0,12 \\
1986 & 0,12 & 0,03 & 0,03 & 0,43 & 0,29 & 0,00 & 0,00 & 0,01 & 0,11 \\
1987 & 0,05 & 0,05 & 0,02 & 0,26 & 0,14 & 0,01 & 0,01 & 0,01 & 0,08 \\
1988 & 0,06 & 0,03 & 0,02 & 0,28 & 0,16 & 0,00 & 0,00 & 0,01 & 0,06 \\
1989 & 0,17 & 0,05 & 0,03 & 0,47 & 0,32 & 0,00 & 0,00 & 0,01 & 0,12 \\
1990 & 0,17 & 0,05 & 0,03 & 0,46 & 0,32 & 0,00 & 0,00 & 0,01 & 0,12 \\
1991 & 0,10 & 0,01 & 0,02 & 0,34 & 0,21 & 0,00 & 0,00 & 0,00 & 0,11 \\
1992 & 0,06 & 0,05 & 0,02 & 0,25 & 0,13 & 0,01 & 0,00 & 0,01 & 0,07 \\
1993 & 0,06 & 0,04 & 0,03 & 0,28 & 0,14 & 0,01 & 0,00 & 0,01 & 0,09 \\
1994 & 0,06 & 0,04 & 0,02 & 0,27 & 0,14 & 0,01 & 0,00 & 0,01 & 0,08 \\
1995 & 0,09 & 0,01 & 0,02 & 0,32 & 0,19 & 0,00 & 0,00 & 0,00 & 0,10 \\
1996 & 0,10 & 0,01 & 0,02 & 0,38 & 0,23 & 0,00 & 0,00 & 0,01 & 0,10 \\
1997 & 0,14 & 0,04 & 0,03 & 0,44 & 0,29 & 0,00 & 0,00 & 0,01 & 0,11 \\
1998 & 0,03 & 0,04 & 0,02 & 0,21 & 0,08 & 0,00 & 0,00 & 0,01 & 0,07 \\
1999 & 0,06 & 0,00 & 0,01 & 0,35 & 0,21 & 0,00 & 0,00 & 0,01 & 0,12 \\
2000 & 0,06 & 0,04 & 0,03 & 0,28 & 0,15 & 0,01 & 0,01 & 0,01 & 0,07 \\
2001 & 0,15 & 0,04 & 0,03 & 0,47 & 0,33 & 0,00 & 0,00 & 0,01 & 0,12 \\
2002 & 0,06 & 0,03 & 0,02 & 0,30 & 0,16 & 0,00 & 0,00 & 0,01 & 0,09 \\
2003 & 0,07 & 0,04 & 0,02 & 0,33 & 0,17 & 0,00 & 0,00 & 0,01 & 0,11 \\
2004 & 0,08 & 0,02 & 0,02 & 0,34 & 0,20 & 0,00 & 0,00 & 0,01 & 0,11 \\
max & 0,17 & 0,05 & 0,03 & 0,47 & 0,33 & 0,01 & 0,01 & 0,01 & 0,12 \\
min & 0,03 & 0,00 & 0,01 & 0,21 & 0,08 & 0,00 & 0,00 & 0,00 & 0,06 \\
average & 0,09 & 0,03 & 0,02 & 0,34 & 0,20 & 0,00 & 0,00 & 0,01 & 0,10 \\
\hline & & & & & & & & &
\end{tabular}

hingga Desember 2004 mempunyai nilai maksimum dan minimum pada komponen yang sama. Komponen pasang surut yang paling dominan secara berturut turut yaitu K1 sebesar 0,42 meter dan 0,47 meter yang dipengaruhi oleh perubahan deklinasi bulan dan paling rendah pada MS4 sebesar 0,00 meter. Hasil perolehan komponen pasang surut menunjukkan nilai periode yang lebih mendekati komponen pasang surut yang dikemukakan oleh (Hydrographic S, 1987). Semakin panjang data yang digunakan, maka kualitas data observasi akan semakin baik karena penunjukkan nilai periode semakin tepat dengan nilai amplitudonya. Panjang periode data observasi berpengaruh penting pada proses kalkulasi untuk memperoleh bilangan komponen pasang surut. Semakin panjang data observasi yang digunakan maka semakin panjang pula komponen pasang surut periode panjang yang dihasilkan.

\section{Komponen Harmonik Fase}

Hasil perhitungan komponen fase $\left(^{\circ}\right)$ dengan metode admiralty yang diperoleh dari skema data pasang surut Maret 2018 dengan menggunakan metode admiralty yang diperoleh konstanta harmonik pasang surut fase yaitu M2, S2, N2, K1, O1, M4, MS4, K2 dan P1. Hasil perhitungan dapat dilihat pada Tabel 7.

Berdasarkan hasil perhitungan komponen fase $\left.{ }^{\circ}\right)$ metode admiralty yang diperoleh dari data pasang surut Januari 1984 hingga Desember 2004 dengan menggunakan metode admiralty yang diperoleh konstanta harmonik pasang surut fase yaitu M2, S2, N2, K1, O1, M4, MS4, K2 dan P1. Hasil perhitungan dapat dilihat pada Tabel 8 .

Hasil perhitungan komponen fase $\left(^{\circ}\right)$ dengan metode least square yang diperoleh dari data pasang surut pada Maret 2018 dengan menggunakan metode

Tabel 7. Hasil Perhitungan Komponen Fase $\left({ }^{\circ}\right)$ Metode Admiralty Bulan Maret 2018

\begin{tabular}{lllllllllll}
\hline $\mathbf{g ( 0 )}$ & S0 & M2 & S2 & N2 & K1 & O1 & M4 & MS4 & K2 & P1 \\
\hline & 0,00 & 331,01 & 338,23 & 81,19 & 249,64 & 85,26 & 302,87 & 309,64 & 338,23 & 249,64 \\
\hline
\end{tabular}

Karakteristik Pasang Surut di Teluk Jakarta Berdasarkan Data 253 Bulan - Aufi Dina 'Amalina, Warsito Atmodjo \& Widodo Setiyo Pranowo 
Tabel 8. Hasil Perhitungan Komponen Fase $\left(^{\circ}\right)$ Metode Admiralty Tahunan Rerata

\begin{tabular}{lllllllllll}
\hline Tahun & \multicolumn{7}{c}{ Komponen Fase $\left(^{\circ}\right.$ ) Rerata dengan Metode Admiralty } \\
\cline { 2 - 10 } & M2 & S2 & N2 & K1 & O1 & M4 & MS4 & K2 & P1 \\
\hline 1984 & 223,05 & 284,80 & 191,18 & 175,86 & 170,75 & 207,47 & 238,33 & 284,80 & 175,86 \\
1985 & 172,39 & 285,24 & 198,55 & 177,54 & 177,22 & 165,73 & 157,34 & 285,24 & 177,54 \\
1986 & 153,54 & 254,53 & 181,60 & 179,52 & 215,70 & 158,40 & 108,61 & 254,53 & 179,52 \\
1987 & 194,77 & 255,26 & 165,63 & 181,66 & 193,87 & 181,27 & 180,02 & 255,26 & 181,66 \\
1988 & 184,79 & 254,79 & 175,16 & 185,13 & 179,09 & 159,51 & 259,12 & 254,79 & 185,13 \\
1989 & 163,89 & 255,14 & 182,94 & 187,26 & 184,88 & 178,28 & 178,42 & 255,14 & 187,26 \\
1990 & 144,72 & 255,14 & 194,21 & 189,12 & 222,98 & 140,86 & 129,69 & 255,14 & 189,12 \\
1991 & 215,87 & 254,94 & 147,73 & 190,63 & 172,57 & 223,06 & 200,82 & 254,94 & 190,63 \\
1992 & 174,70 & 314,67 & 186,89 & 192,38 & 158,73 & 140,11 & 159,39 & 314,67 & 192,38 \\
1993 & 182,87 & 314,96 & 165,39 & 192,05 & 196,89 & 217,31 & 198,03 & 314,96 & 192,05 \\
1994 & 163,77 & 344,83 & 174,93 & 190,39 & 209,49 & 178,13 & 148,50 & 344,83 & 190,39 \\
1995 & 233,91 & 345,27 & 156,72 & 188,21 & 163,04 & 198,57 & 218,76 & 345,27 & 188,21 \\
1996 & 191,74 & 345,04 & 165,50 & 185,63 & 154,73 & 174,05 & 176,53 & 345,04 & 185,63 \\
1997 & 184,74 & 345,30 & 145,02 & 182,58 & 213,11 & 220,77 & 199,95 & 345,30 & 182,58 \\
1998 & 149,81 & 314,95 & 154,10 & 178,54 & 183,06 & 120,20 & 134,64 & 314,95 & 178,54 \\
1999 & 249,37 & 314,80 & 164,49 & 175,85 & 167,77 & 230,54 & 234,79 & 314,80 & 175,85 \\
2000 & 178,07 & 314,66 & 143,26 & 174,98 & 157,45 & 146,52 & 162,85 & 314,66 & 174,98 \\
2001 & 156,58 & 315,18 & 153,15 & 174,60 & 226,00 & 223,58 & 201,35 & 315,18 & 174,60 \\
2002 & 166,80 & 315,06 & 164,12 & 174,89 & 175,99 & 155,17 & 152,15 & 315,06 & 174,89 \\
2003 & 223,01 & 255,17 & 149,50 & 167,71 & 148,44 & 207,25 & 238,42 & 255,17 & 167,71 \\
2004 & 167,01 & 255,37 & 153,55 & 178,60 & 170,64 & 155,01 & 151,99 & 255,37 & 178,60 \\
max & 249,37 & 345,30 & 198,55 & 192,38 & 226,00 & 230,54 & 259,12 & 345,30 & 192,38 \\
min & 144,72 & 254,53 & 143,26 & 167,71 & 148,44 & 120,20 & 108,61 & 254,53 & 167,71 \\
average & 184,54 & 295,00 & 167,31 & 182,05 & 182,97 & 180,09 & 182,37 & 295,00 & 182,05 \\
\hline & & & & & & & & &
\end{tabular}

least square dengan konstanta harmonik pasang surut fase yaitu M2, S2, N2, K1, O1, M4, MS4, K2 dan P1. Untuk nilai komponen fase $\left({ }^{\circ}\right)$ dapat dilihat pada Tabel 9.

Perhitungan komponen pasang surut menggunakan metode least square sehingga diperoleh nilai komponen fase selama 252 bulan. Hasil komponen fase $\left(^{\circ}\right)$ pada Januari 1984 - Desember 2004 dapat diperoleh nilai maksimum, nilai minimum, serta nilai rerata pada masing - masing komponen fase $\left(^{\circ}\right) \mathrm{M} 2$, S2, N2, K1, O1, M4, MS4, K2 dan P1. Nilai maksimum, minimum, dan rerata pada masing - masing komponen fase dapat dilihat di Tabel 10.

Hasil perhitungan komponen fase $\left(^{\circ}\right)$ dengan menggunakan metode admiralty yang diperoleh dari data pasang surut selama 253 bulan dengan menggunakan metode admiralty dengan konstanta harmonik pasang surut amplitudo yaitu M2, S2, N2, $\mathrm{K} 1, \mathrm{O} 1, \mathrm{M} 4, \mathrm{MS} 4, \mathrm{~K} 2$ dan P1.Pada komponen ini yang merupakan komponen dominan adalah komponen S2 dan M2 yang merupakan komponen fase pasang surut yang paling dominan dikarenakan komponen pasang surut ganda utama yang dipengaruhi oleh gravitasi dari bulan dan matahari terhadap bumi, selain itu juga dipengaruhi oleh faktor lokal seperti kedalaman perairan dan teluk yang dapat mempengaruhi kondisi pasang surut di suatu daerah.Paling non dominan yaitu komponen N2 dan MS4 yang dikarenakan oleh perubahan jarak akibat lintasan bulan yang ellips serta kecepatan sudutnya dua kali lipat dipengaruhi oleh bulan. Sedangkan hasil perhitungan least square pada komponen fase selama bulan Maret 2018 dan Januari 1984 hingga Desember 2004 mempunyai komponen paling besar dan paling rendah yang sama.

Tabel 9. Hasil Perhitungan Komponen Fase $\left(^{\circ}\right)$ Metode Least Square Maret 2018

\begin{tabular}{|c|c|c|c|c|c|c|c|c|c|}
\hline \multicolumn{10}{|c|}{ Komponen Fase Tahunan $\left({ }^{\circ}\right)$ Rerata } \\
\hline $\mathrm{g}\left({ }^{\circ}\right)$ & M2 & $\mathrm{S} 2$ & N2 & K1 & O1 & M4 & MS4 & $\mathrm{K} 2$ & P1 \\
\hline & 170,27 & 130,81 & 188,99 & 29,85 & 148,03 & 356,70 & 232,98 & 153,21 & 36,92 \\
\hline
\end{tabular}


Tabel 10. Hasil Perhitungan Komponen Fase $\left(^{\circ}\right)$ Tahunan Rerata Least Square

\begin{tabular}{lllllllllll}
\hline Tahun & \multicolumn{7}{c}{ Komponen Fase $\left(^{\circ}\right)$ Rerata dengan Metode Least Square } \\
\cline { 2 - 10 } & M2 & S2 & N2 & K1 & O1 & M4 & MS4 & K2 & P1 \\
\hline 1984 & 299,13 & 75,42 & 254,67 & 34,98 & 163,35 & 30,45 & 300,44 & 97,82 & 42,05 \\
1985 & 327,62 & 143,42 & 254,32 & 37,14 & 150,89 & 3,98 & 297,84 & 165,82 & 44,21 \\
1986 & 338,09 & 263,75 & 280,17 & 38,27 & 140,40 & 301,08 & 272,34 & 286,15 & 28,08 \\
1987 & 282,04 & 68,94 & 230,12 & 29,69 & 168,56 & 33,37 & 269,98 & 91,34 & 26,00 \\
1988 & 306,04 & 76,39 & 257,77 & 31,36 & 159,98 & 11,54 & 276,88 & 98,79 & 36,91 \\
1989 & 344,31 & 246,29 & 295,55 & 39,23 & 136,57 & 260,98 & 160,93 & 268,69 & 48,76 \\
1990 & 344,44 & 246,29 & 295,78 & 39,71 & 136,20 & 260,93 & 147,34 & 268,69 & 48,87 \\
1991 & 328,61 & 1,11 & 264,13 & 38,35 & 145,73 & 327,71 & 288,67 & 23,51 & 45,42 \\
1992 & 293,87 & 82,82 & 235,56 & 33,57 & 170,37 & 46,82 & 330,21 & 105,22 & 29,83 \\
1993 & 310,72 & 89,78 & 248,40 & 41,43 & 151,64 & 33,28 & 311,62 & 112,18 & 48,50 \\
1994 & 304,80 & 89,95 & 248,41 & 38,70 & 158,38 & 45,53 & 314,49 & 112,35 & 45,80 \\
1995 & 332,33 & 87,47 & 281,69 & 42,93 & 144,13 & 24,06 & 322,47 & 109,87 & 29,61 \\
1996 & 332,54 & 195,09 & 271,52 & 45,52 & 134,12 & 140,87 & 300,79 & 330,98 & 53,40 \\
1997 & 341,52 & 230,82 & 288,37 & 46,46 & 127,75 & 268,11 & 31,06 & 253,22 & 60,60 \\
1998 & 243,65 & 70,86 & 199,63 & 10,86 & 127,07 & 61,01 & 300,83 & 93,26 & 17,93 \\
1999 & 323,69 & 153,99 & 280,56 & 43,55 & 145,14 & 42,45 & 319,56 & 126,97 & 50,62 \\
2000 & 288,41 & 78,53 & 233,29 & 36,39 & 163,80 & 47,88 & 305,14 & 100,93 & 35,01 \\
2001 & 344,24 & 244,80 & 298,22 & 43,66 & 132,33 & 270,43 & 324,56 & 267,20 & 43,15 \\
2002 & 329,69 & 60,34 & 250,27 & 37,98 & 160,33 & 46,31 & 302,24 & 106,44 & 41,08 \\
2003 & 310,37 & 85,76 & 258,99 & 38,75 & 159,68 & 25,25 & 321,45 & 108,16 & 45,82 \\
2004 & 318,96 & 88,69 & 246,63 & 32,51 & 151,81 & 340,28 & 282,00 & 111,09 & 39,58 \\
max & 344,44 & 263,75 & 298,22 & 46,46 & 170,37 & 340,28 & 330,21 & 330,98 & 60,60 \\
min & 243,65 & 1,11 & 199,63 & 10,86 & 127,07 & 3,98 & 31,06 & 23,51 & 17,93 \\
average & 316,43 & 127,64 & 260,67 & 37,19 & 148,96 & 124,87 & 275,28 & 154,22 & 41,01 \\
\hline & & & & & & & & &
\end{tabular}

Komponen pada Maret 2018 yang paling besar yaitu M4 sebesar $356,70^{\circ}$ dan paling rendah secara berturut - turut yaitu K1 sebesar 29,85. Pada komponen ini dipengaruhi oleh kecepatan sudut dua kali lipat oleh bulan dan dipengaruhi oleh perubahan deklinasi bulan dan matahari. Pada Januari 1984 hingga Desember 2004 menunjukkan nilai tertinggi pada komponen M2 sebesar $344,44^{\circ}$ dan nilai terendah pada komponen S2 sebesar $1,11^{\circ}$. Pada komponen ini baik rendah maupun tinggi merupakan komponen pasang surut ganda utama yang dipengaruhi oleh gravitasi bulan dan matahari terhadap bumi, selain itu juga dipengaruhi oleh faktor lokal seperti kedalaman perairan dan teluk yang dapat mempengaruhi kondisi pasang surut di suatu daerah.

\section{Formzahl dan Tipe Pasang Surut}

Berdasarkan hasil perhitungan formzahl pada Maret 2018 dengan metode admiralty menghasilkan bilangan formzahl sebesar 2,67 yang tergolong kedalam tipe pasang surut campuran cenderung tunggal sementara pada perhitungan menggunakan metode least square menghasilkan nilai formzahl sebesar 3,78 dengan tipe pasang surut tunggal. Sedangkan pada perhitungan Januari 1984 hingga Desember 2004 metode admiralty diperoleh nilai formzahl sebesar
3,69 dan tipe pasang surut tunggal dan pada metode least square diperoleh nilai formzahl sebesar 4,65 dan tipe pasang surut tunggal.

Ongkosongo \& Suyarso (1989) serta Haryono \& Narni (2004) bahwa Laut Jawa didominasi oleh kombinasi karakteristik pasang surut harian tunggal dan harian ganda. Wyrtki (1961) karakteristik peta pasang surut wilayah Barat memiliki tipe pasang surut tunggal dan harian cenderung tunggal. Berdasarkan hasil perhitungan formzahl pada Maret 2018 dengan metode admiralty menghasilkan bilangan formzahl sebesar 2,67 yang tergolong kedalam tipe pasang surut campuran cenderung tunggal sementara pada perhitungan menggunakan metode least square menghasilkan nilai formzahl sebesar 3,78 dengan tipe pasang surut tunggal. Sedangkan pada perhitungan Januari 1984 hingga Desember 2004 metode admiralty diperoleh nilai formzahl sebesar 3,69 dan tipe pasang surut tunggal dan pada metode least square diperoleh nilai formzahl sebesar 4,65 dan tipe pasang surut tunggal. Hal ini diperkuat oleh Wyrtki (1961) serta Ongkosongo (1989) dan Haryono (2004) yaitu berturut - turut tunggal dan campuran condong ke harian tunggal. Perbedaan karakteristik pasang surut diakibatkan 
kualitas data observasi yang digunakan.

Perbedaan hasil dari metode admiralty dengan least square selama 253 bulan mempunyai nilai yang berbeda - beda secara sistematis terhadap siklus bulan. Rentang pasang surut juga bergantung pada bentuk perairan dan konfigurasi lantai samudera, karena sifat pasang surut yang periodik maka dapat diramalkan. Pasang surut air laut dipengaruhi oleh kedalaman dan luas perairan, pengaruh rotasi bumi, gesekan dasar, topografi dasar laut, lebar selat, bentuk teluk. Teluk yang berupa pantai landai akan berbeda dengan teluk yang berupa tebing curam, apabila ketika terjadi pasang. Pantai yang landau akan lebih terlihat pasang apabila dibandingkan dengan dinding jurang yang curam karena ditahan oleh dinding jurang tersebut. Periode data pasang surut yang berbeda akan menghasilkan jumlah konstanta harmonik yang berbeda, sehingga akan mempengaruhi nilai chart datum yang dihasilkan. Perbedaan nilai amplitudo yang dihasilkan oleh kelompok data periode panjang dapat disebabkan faktor astronomis, pengaruh non linier, dan variasi dari topografi bawah laut. Semakin lama pengamatan data pasang surut maka faktor - faktor penyebab pasang surut akan dapat teridentifikasi sehingga konstanta - konstanta harmonik pasang surut yang dihasilkan semakin banyak (Khasanah et al., 2017).

Konstituen harmonik komponen tunggal utama terdiri dari $\mathrm{O} 1$ dan K1. Konstituen tersebut memberikan efek yang besar pada pembangkitan gelombang pasang surut bertipe tunggal. Fenomena yang terjadi pada komponen tunggal, secara umum sama dengan fenomena hasil penelitian Zuke et al. (1997), dimana konstituen Q1, P1, O1, dan K1 merupakan konstituen relatif tidak stabil akibat faktor astronomi. Faktor astronomi yang dimaksud adalah potensi bangkitan pasang surut (generating potential) dari pengaruh bulan yang dinotasikan dengan V3 untuk nilai phase lag L2 (ekliptik bulan terkecil) sebesar $25 \%$ merujuk pada posisi matahari yang menyebabkan ketidakstabilan konstituen harmonik komponen tunggal O1, K1, P1 dan Q1. Hal ini berbeda dengan nilai pada posisi bulan dengan nilai V3 yang relatif kecil sehingga amplitudo konstituen harmonik relatif stabil (Zuke et al., 1997 dalam Salnuddin et al., 2015).

\section{KESIMPULAN DAN SARAN}

Berdasarkan hasil penelitian dapat disimpulkan bahwa perairan Teluk Jakarta mempunyai nilai elevasi pada bulan Maret 2018 berturut - turut yaitu Z0 senilai 1,72 meter, MSL senilai 1,909 meter, MHWL senilai
2,544 meter, MLWL senilai 1,274 meter dan Tunggang senilai 1,270 meter. Berdasarkan nilai tahunan pada Z0 nilai maksimum sebesar 1,92 meter; $Z_{0}$ nilai minimum sebesar 1,57 meter; dan $Z_{0}$ nilai rerata sebesar 1,75 meter. Untuk nilai pada MSL nilai maksimum sebesar 2,09 meter; nilai minimum sebesar 1,79 meter; nilai rerata sebesar 1,94 meter. Pada nilai MHWL dengan nilai maksimum sebesar 3,17 meter; nilai minimum sebesar 2,52 meter; dan nilai rerata sebesar 2,81 meter. Sedangkan nilai MLWL diperoleh nilai maksimum yaitu 1,36 meter; nilai minimum yaitu 0,63 meter; dan nilai rerata yaitu 1,08 meter. Sehingga diperoleh nilai tunggang nilai maksimum sebesar 2,53 meter; nilai minimum sebesar 1,17 meter; dan nilai rerata sebesar 1,72 meter. Komponen harmonik amplitudo menggunakan metode admiralty pada Maret 2018 diperoleh nilai maksimum pada komponen M4 senilai 3,75 dan nilai minimum senilai 0,02 pada komponen N2 dan K2. Sedangkan komponen harmonik amplitudo rerata tahunan pada nilai maksimum senilai 4,25 dengan komponen M4, nilai minimum senilai 0,02 dengan komponen K2 dan nilai rerata tertinggi senilai 3,97 untuk komponen M4 dan terendah senilai 0,01 untuk komponen K2. Sesuai dengan perhitungan komponen harmonik amplitudo rerata tahunan menggunakan metode least square pada nilai maksimum senilai 0,47 dengan komponen $\mathrm{K} 1$, nilai minimum senilai 0,00 dengan komponen S2, K2, M4, MS4 dan nilai rerata tertinggi senilai 0,34 untuk komponen $\mathrm{K} 1$ dan terendah senilai 0,00 untuk komponen M4, MS4. Pada komponen harmonik amplitudo bulan Maret 2018 nilai maksimum sebesar 0,42 meter untuk komponen K1 dan 0,00 meter pada komponen M4, MS4. Komponen harmonik fase menggunakan metode admiralty pada Maret 2018 diperoleh nilai maksimum pada komponen $\mathrm{S} 2$ dan $\mathrm{K} 2$ senilai $338,23^{\circ}$ dan nilai minimum senilai $81,19^{\circ}$ pada komponen N2. Sedangkan komponen harmonik fase rerata tahunan pada nilai maksimum senilai $345,30^{\circ}$ dengan komponen $\mathrm{K} 2$ dan S2, nilai minimum senilai $108,61^{\circ}$ dengan komponen MS4 dan nilai rerata tertinggi senilai $295^{\circ}$ untuk komponen S2 dan K2 dan terendah senilai $167,31^{\circ}$ untuk komponen N2. Sesuai dengan perhitungan komponen harmonik fase rerata tahunan menggunakan metode least square pada nilai maksimum senilai $344,44^{\circ}$ dengan komponen $\mathrm{M} 2$, nilai minimum senilai $1,11^{\circ}$ dengan komponen S2 dan nilai rerata tertinggi senilai $316,43^{\circ}$ untuk komponen M2 dan terendah senilai $37,19^{\circ}$ untuk komponen K1, Pada komponen harmonik fase bulan Maret 2018 nilai maksimum sebesar 356,70 untuk komponen M4 dan minimum sebesar 36,92 untuk komponen P1. Nilai formzahl pada perairan Teluk Jakarta dengan menggunakan metode admiralty 
berkisar antara 2,67 hingga 3,69 sedangkan pada metode least square berkisar antara 3,78 hingga 4,65 sehingga mempunyai variasi tipe pasang surut yaitu campuran cenderung tunggal dan tunggal.

\section{UCAPAN TERIMA KASIH}

Artikel ini adalah bagian dari skripsi ditulis oleh penulis pertama dengan dibimbing oleh para penulis kedua dan ketiga. Ucapan terimakasih ditujukan untuk Kapten Laut Choirul Umam (Sekolah Tinggi Teknologi Angkatan Laut) Prodi Hidrografi yang mendampingi ke Stasiun Pasut Kolinlamil, Saudara Tonny Adam Theoyana yang memberikan arahan dalam pengolahan data skripsi, Bapak Purwanto dan Bapak Hariyadi selaku penguji pada saat ujian skripsi. Pengolahan dan analisis data dilakukan di Laboratorium Data Laut dan Pesisir, Pusat Riset Kelautan, BRSDMKP, Ancol Timur, Jakarta Utara.

\section{DAFTAR PUSTAKA}

Arifiyanto., Pranowo, W. S., Fatoni, K. I., \& Kuswardani, A. R. T. D. (2016). Pengolahan dan Penyajian Data Arus Pasang Surut Hasil Pengukuran Acoustic Doppler Current Profiler (ADCP) SonTek Argonout-XR Menggunakan Perangkat Lunak T_Tide_V1.3beta. Jurnal Hidropilar, 1(2): ISSN 2460 - 4607.

Abida, R.F., Pranowo, W.S., Pratomo, Y., \& Kisnarti. E. A. (2015). Identifikasi Komponen Harmonik di Selat Lombok Berdasarkan Data Arus Time Series. Jurnal Depik, 4(1): 24 - 32.

Gumelar, J., Sasmito, B., \& Amarrohman, F. J. (2016). Analisis Harmonik Dengan Menggunakan Teknik Kuadrat Terkecil Untuk Penentuan Komponen - Komponen Pasut Di Wilayah Laut Selatan Pulau Jawa Dari Satelit Altimetri Topex/ Poseidon Dan Jason-1. Jurnal Geodesi Undip, 5(1): 194 - 203.

Handoyo, G., Suryosaputro, A. A. D. \& Pratikyo, I. (2015). Konversi Tinggi Pasang Surut Di Perairan Cilacap Terhadap Energi Yang Dihasilkan. Jurnal Kelautan Tropis, 18(2): 112 $-120$.

Haryono \& Narni, S. (2004). Karakteristik Pasang Surut Laut di Pulau Jawa. Jurnal Forum Teknik, 28(1): 1-5.
Hydrographic, S. (1987). Physical Oceanographic Survey Course. Group Training Couse in Hydrographic Service. Tokyo, $51 \mathrm{p}$.

Jamalludin., Fatoni, K. I., Alam, T. M., \& Pranowo, W.S. (2016). Identifikasi Banjir Rob Periode 2013 - 2015 Di Kawasan Pantai Utara Jakarta. Jurnal Chart Datum, 2(2): 1-11.

Khasanah, I. U., Wirdinata, S., \& Guvil, Q. (2017). Analisis Harmonik Pasang Surut untuk Menghitung Nilai Muka Surutan Peta (Chart Datum) Stasiun Pasut Sibolga. Seminar Nasional Strategi Pengembangan Infrastruktur di Institut Teknologi Padang Tanggal 27 Juli 2017. Padang, pp. $243-249$.

Khatimah, H., Jaya, I., \& Atmadipoera, A. S. (2016). Pengembangan Perangkat Lunak Antar Muka Instrumen Motiwali (Tide Gauge) Untuk Analisis Data Pasang Surut. Jurnal Kelautan Nasional, 11(2): 97-104.

Kusmanto, E., Hasanudin, M., \& Setyawan, W. B. (2016). Amplifikasi Pasang Surut dan Dampaknya Terhadap Perairan Pesisir Probolinggo. Jurnal Oseanologi dan Limnologi di Indonesia, 1(3): 69-80.

Muldiyatno, F., Djunarsjah, E., Adrianto, D., \& Pranowo, W.S. (2016). Kajian Awal Perubahan Muka Air Sungai Untuk Penentuan Datum Peta (Studi Kasus Sungai Musi Palembang). Jurnal Chart Datum, 1(2): 36-42.

Nazir, M. (1988). Metode Penelitian. Ghalia Indonesia, Jakarta, $544 \mathrm{hlm}$.

Nontji, A. (1987). Laut Nusantara. Djambatan, Jakarta, $358 \mathrm{hlm}$.

Ongkosongo, O. S. R., \& Suyarso. (1989). Pasang Surut. Lembaga Ilmu Pengetahuan Indonesia Pusat Penelitian dan Pengembangan Oseanologi, Jakarta, $257 \mathrm{hlm}$.

Pawlowicz, R., Beardsley, B., \& Lentz, S. (2002). Classical Tidal Harmonic Analysis Including Error Estimates in Matlab Using T_Tide. $J$. Pergamon, 28: 929-937.

Poerbandono \& Djunarsjah, E. (2005). Survey Hidrografi. Refika Aditama, Bandung, $166 \mathrm{hlm}$. 
Putra, A. Y. N., \& Pratomo, D. G. (2017). Pengembangan Co-Tidal Charts Untuk Analisis Karakteristik Pasang Surut Perairan Laut Jawa. Jurnal Teknik, 6(2): G204-G207.

Salnuddin., Nurjaya, I. W., Jaya, I., \& Natih, N. M. N. (2015). Variasi Amplitudo Konstituen Harmonik Pasang Surut Utama di Stasiun Bitung, Sulawesi Selatan. Jurnal Ilmu Kelautan, 20(2): 73-86.

Supriyono., Pranowo, W. S., Rawi, S., \& Herunadi, B. (2015). Analisis dan Perhitungan Prediksi Pasang Surut Menggunakan Metode Admiralty dan Metode Least Square (Studi Kasus Perairan Tarakan dan Balikpapan. Jurnal Chart Datum, 1(1): $8-18$.

Trenggono, M., Priyono, B., Agustiadi, T., Rahman, M. A., \& Sukadana, G. P. (2015). Pemantauan Elevasi Muka Air Selat Bali dengan Menggunakan Stasiun Pasang Surut. Research Gate, $39-47$.

Widisantosa, H., Pranowo, W. S., Simajuntak, S. M., \& Setiadi, H. (2016). Studi Konstanta Harmonik Pasang Surut Terhadap Data Suhu Permukaan Laut di Perairan Pulau Pari. Jurnal Chart Datum, 2(2): 32-43.

Wyrtki. (1961). Physical Oceanography of The Southest Asian Waters. Naga Report, 2. Sripps Institution of Oceanography. The University of California, California, $226 \mathrm{p}$.

Zuke, H., Zongyong, C., \& Hongye, S. I. (1997). Analysis of 19 year tidal data. Science in China, 40(4): 352-360. 